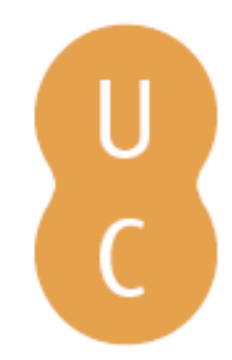

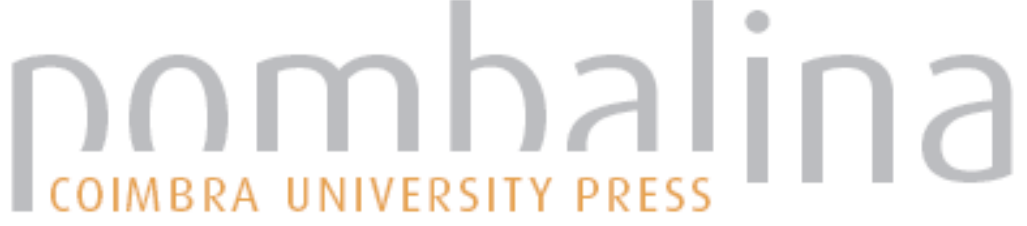

\section{Ethopoeia no romance bizantino do século XII}

\author{
Autor(es): Ruas, Vítor \\ Publicado por: Centro de Estudos Clássicos e Humanísticos \\ URL \\ persistente: \\ URI:http://hdl.handle.net/10316.2/39256 \\ DOI: \\ DOI:http://dx.doi.org/10.14195/978-989-26-1229-4_14
}

Accessed : $\quad$ 26-Apr-2023 14:23:36

A navegação consulta e descarregamento dos títulos inseridos nas Bibliotecas Digitais UC Digitalis, UC Pombalina e UC Impactum, pressupõem a aceitação plena e sem reservas dos Termos e Condições de Uso destas Bibliotecas Digitais, disponíveis em https://digitalis.uc.pt/pt-pt/termos.

Conforme exposto nos referidos Termos e Condições de Uso, o descarregamento de títulos de acesso restrito requer uma licença válida de autorização devendo o utilizador aceder ao(s) documento(s) a partir de um endereço de IP da instituição detentora da supramencionada licença.

Ao utilizador é apenas permitido o descarregamento para uso pessoal, pelo que o emprego do(s) título(s) descarregado(s) para outro fim, designadamente comercial, carece de autorização do respetivo autor ou editor da obra.

Na medida em que todas as obras da UC Digitalis se encontram protegidas pelo Código do Direito de Autor e Direitos Conexos e demais legislação aplicável, toda a cópia, parcial ou total, deste documento, nos casos em que é legalmente admitida, deverá conter ou fazer-se acompanhar por este aviso. 
FRANCISCO DE OLIVEIRA

PAOLO FEDELI

DELFIM LEÃO

Coordenadores

\section{- ROMANCE ANTIGO ORIGENS DE UM GÉNERO LITERÁRIO}

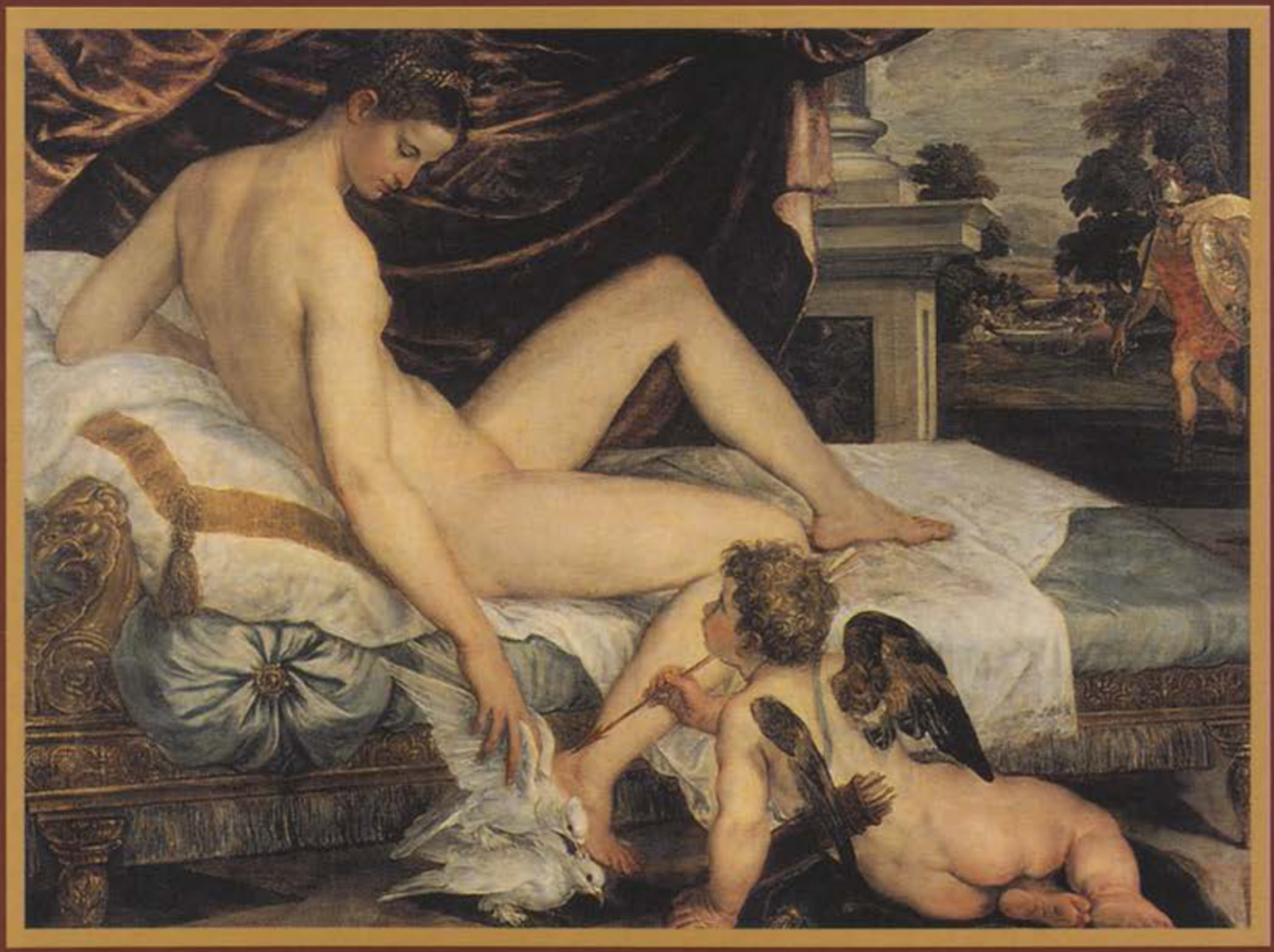

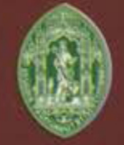

Universidade de Coimbra

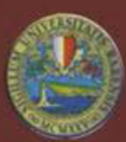

Università degli Studi di Bari

COIMBRA

2005 


\title{
ETHOPOEIA NO ROMANCE BIZANTINO DO SÉCULO XII
}

\author{
VÍTOR RUAS \\ Universidade dos Açores
}

\begin{abstract}
Ethopoeia is one of the most important rhetorical devices in the Byzantine novel of the twelfth century. Sixty to seventy per cent of this literary production consists of direct speech, either under the form of monologue or dialogue. And, particularly, Eumathios Makrembolites' novel, which is told in the first person, becomes lato sensu a long ethopoeia. The main models for the use of this rhetorical device are the Progymnasmata of the Second Sophistic, the handbooks for training textual composition. In the Progymnasmata, Hermogenes and Aphtonios define ethopoeia as the rhetorical device which is responsible for expressing a person's character as he or she makes a speech. When inserted in the novel, ethopoeia assures a literary duration and gives the text a narrative function. The disposition of the ethopoeia plays thus a geotextual role, since it obeys to narrative criteria which are made to meet the expectations of the reading or hearing public. The immediacy created by the quotation gives the narrative sequence a dramatic nature. And, finally, it plays an important role in the general process of characterisation.
\end{abstract}

Depois de um hiato de oito séculos, 'o género romanesco aparece revitalizado no início do século XII ${ }^{2}$ sob a égide dos Comnenos. ${ }^{3}$ Deste período, chegaram até nós quatro exemplares romanescos: três de

${ }^{1}$ No período que medeia entre o florescimento do romance antigo e o seu ressurgimento no império bizantino, a ficção narrativa cristã substituiu, lato sensu, o género romanesco; e deste recebeu uma enorme influência, o que comprova a vitalidade e poder de sedução que o género romanesco possuía. G. SCHMELING explica esta influência nos seguintes termos: «The fact that ancient novels cease to be written about the time that saints' lives and hagiographic romances begin supports the notion that the latter grew out of the former» in SCHMELING (1980) 142. Para um conhecimento mais profundo sobre este assunto, uide PERVo (1996) 685-709 e Hock et alii (1998).

${ }^{2}$ Sobre a datação dos romances bizantinos do século XII, uide HUNGER (1998) 1-28. Cf., neste mesmo artigo, outras propostas de datação.

${ }^{3} \mathrm{Da}$ dinastia dos Comnenos fizeram parte os seguintes imperadores: Aleixo I (1081-1118), que foi coroado imperador no Domingo de Páscoa de 4 de Abril de 1081, tendo os Comnenos reconquistado o poder depois do reinado de Isaac I (1057-1059); João II (1118-1143); Manuel I (1143-1180); Aleixo II (1180-1183); e Andronico I (1183-1185). 
forma integral (Hismine e Hisminias de Eumátio Macrembolites, Rodante e Dósicles de Teodoro Pródromo e Drosila e Cáricles de Nicetas Eugeniano) e um romance sob a forma de fragmentos (Aristandro e Calitea de Constantino Manasses). ${ }^{4}$

Apenas um destes quatro romances foi escrito em prosa - Hismine e Hismínias de Eumátio Macrembolites. Os restantes três foram compostos em verso. Embora seja difícil encontrar uma explicação completamente satisfatória para a preferência pelo verso, pode-se, contudo, afirmar que tal se deve ter ficado a dever à popularidade que a épica granjeou entre os bizantinos. $\mathrm{O}$ verso surge igualmente na historiografia, de que é exemplo a Crónica Sinóptica de Constantino Manasses, uma crónica breve da história do mundo que se acredita ter sido composta entre 1143 e $1152 .^{5}$ Neste caso, tal como sucede nos romances bizantinos, trata-se de uma prosa versejada. O verso constitui uma forma textual predilecta, sem que sobre ela recaia uma avaliação de ordem estética que é própria da poesia. ${ }^{6}$ É neste sentido que se pode falar em prosa versejada e em lírica em prosa.

Os autores dos romances bizantinos do século XII pertenciam ao círculo literário apadrinhado pela dinastia dos Comnenos. ${ }^{8}$ Pelo menos três destes autores - Teodoro Pródromo, Nicetas Eugeniano e Constantino Manasses - mantinham uma relação muito próxima com membros da aristocracia imperial. Teodoro Pródromo exerceu a actividade de escritor na casa imperial, tendo-se dedicado não só a temas de carácter religioso, como também a temáticas da antiguidade pagã. ${ }^{9}$ Por seu turno, Nicetas Eugeniano foi discípulo de Pródromo; e, por altura da morte do seu mestre, compôs três monódias: uma em prosa e duas

${ }^{4}$ Os romances bizantinos do século XII estão editados, e traduzidos para a língua italiana, in CONCA (1994). Vide outras edições e traduções: BURTON (2004); Conca (1990); MARCovich (1992 e 2001); MAZAL (1967); Meunier (1991); Moreno JuRAdo (1996); PLEPELITS (1989, 1996 e 2003).

${ }^{5}$ Cf. LAMPSidis (1996).

${ }^{6}$ Convirá aqui lembrar que, de entre os três géneros aristotélicos, o género epidíctico foi aquele que conheceu um mais proficuo desenvolvimento, tendo sofrido a influência, por exemplo, de géneros que tradicionalmente eram elaborados em verso, como o hino e o epitalâmio.

${ }^{7}$ Sobre as fronteiras nem sempre muito fixas dos diferentes géneros literários, uide DERRIDA (1980) 185. Vide, ainda, sobre o relativismo das formulações genológicas, REIS (1995) 284-296.

${ }^{8}$ Vide, sobre o assunto, JeFFreys (1980) 478-481; ANGOLD (1984) 204-205 e (1997) 246-249; MAGDALINO (1993) 350-351; e WiLSON (1996) 182-183.

${ }^{9}$ Cf. KAZHDAN (1984) 87-114; CONCA (1994) 20; e BEATON (1996a) 70. 
em verso. ${ }^{10}$ Também sabemos que a Crónica Sinóptica foi encomendada a Constantino Manasses por Irene Sebastocratorissa. ${ }^{11}$ Eumátio Macrembolites, por sua vez, fez carreira na administração imperial e terá escrito o seu romance, ainda bastante novo, quando desempenhava a função de notário (circa 1130-1135). ${ }^{12}$

A partir do momento em que os Comnenos reconquistaram o poder (1081), Constantinopla passou a gozar de estabilidade política e económica. A actividade literária intensificou-se. Surgiram, então, literatos profissionais que eram incentivados pela família imperial a produzir não só comentários sobre obras de renome da antiguidade, como também novas composições literárias. Por exemplo, Ana Comnena, filha de Aleixo I, incentivou a produção de novos comentários sobre Aristóteles. ${ }^{13}$ A defesa de um domínio exemplar do grego ático passou igualmente a constituir uma prioridade na corte imperial. ${ }^{14}$ $\mathrm{E}$, como consequência, o registo linguístico dos romances bizantinos deste período corresponde a uma língua artificial, tendencialmente ancorada no grego ático, mas com inúmeros influxos bíblicos.

É neste quadro de referências que vemos surgir em Constantinopla um interesse bastante significativo pelos estudos de retórica, ${ }^{15}$ que passam a ter um lugar privilegiado no sistema educativo bizantino, a par dos estudos de natureza teológica. ${ }^{16}$ Os literatos profissionais, assim como os funcionários da administração imperial, dominam as principais regras da ars bene dicendi. E este domínio parece constituir uma das principais condições para o seu sucesso profissional.

$\mathrm{Na}$ época bizantina, o ensino da retórica toma por fonte teórica os princípios postulados pelos retores da Segunda Sofística, o movimento sócio-cultural dos primeiros quatro séculos da nossa era. ${ }^{17}$ No

${ }^{10}$ Cf. Conca (1994) 21.

"Cf. CONCA (1994) 20 e BurTon (2004) XII.

${ }^{12}$ Cf. Hunger (1998) 4-8; AGAPITOS (2000) 184-185; e NiLSSON (2001) 18.

${ }^{13}$ Cf. MAgdalino (1993) 332 e BURTON (2004) XII.

${ }^{14}$ Sobre este tema, uide MAgdalino (1993) 385.

${ }^{15}$ A este respeito, esclarece Roderick BEATON: «Large quantities of rhetorical literature were produced to order at this period [the twelfth century] in Constantinople, to be read or performed aloud either in public or before the more exclusive audience of a theatron - a precursor, perhaps, of the learned academies of the Renaissance», in BEATON (1996b) 714.

${ }^{16}$ Cf. CONSTANTINIDES (2003) 39-40.

${ }^{17}$ Para uma visão sucinta sobre a Segunda Sofística, uide ANDERSON (1989) 79208 e BowIE (1989) 209-258. Sobre o triunfo da Segunda Sofistica, e Filóstrato em particular, uide FUTRE PINHEIRO (2000) 121-128. 
século XII bizantino, assiste-se a um verdadeiro revivalismo da cultura helenística. Os Progymnasmata, ${ }^{18}$ os manuais de treino de composição textual, constituem, neste contexto, a principal fonte de teorização retórica. ${ }^{19}$ A literatura bizantina da época reflecte, de modo bastante evidente, essa influência. ${ }^{20} \mathrm{E}$, na produção romanesca bizantina, em particular, torna-se perfeitamente notória a assimilação numa sequência narrativa de recursos retóricos que os Progymnasmata consagravam autonomamente.

Antes de abordarem o exercício da declamação, os retores da Segunda Sofística obrigavam os seus alunos a exercitar-se numa série de exercícios preliminares. Os exercícios mais simples eram estudados nas aulas do grammatikós, ao passo que os exercícios mais dificeis eram desenvolvidos num ciclo de estudos superiores a cargo do sophistês. Nos Progymnasmata de Élio Téon, Hermógenes de Tarso, Aftónio de Antioquia e Nicolau de Mira são apresentados catorze exercícios preparatórios. ${ }^{21}$ São eles:

- a fábula (mythos/fabula);

- a narração (diêgêma/narratio);

- a cria (chreia/usus);

- a máxima ou provérbio (gnômê/sententia);

- a refutação (anaskeuê/subuertio);

- a confirmação (kataskeuê/confirmatio);

- o lugar comum (koinós topos/locus communis);

- o elogio (enkômion/laus);

- o vitupério (psógos/uituperatio);

- a comparação (synkrisis/comparatio);

- a etopeia (êthopoiía/adlocutio);

- a descrição (ekphrasis/descriptio);

- a tese ou tema (thésis/argumentum);

- a defesa ou condenação de uma lei (nómou eisphorál legislatio).

${ }^{18}$ Cf. Kennedy (2003).

19 Acerca do estudo dos Progymnasmata no período bizantino, uide HUNGer (1978), 92-120 (vol. I).

${ }^{20}$ Cf. JEFFREYS (2003) 1-5.

21 Cf. Kennedy (2003). Cf., também, Walz (1832-36); Spengel (1854-56); Rabe (1913 e 1926); Felten (1913); Butts (1986); Reche Martínez (1991); e PATILLON (1997). Acerca dos exercícios preparatórios de Libânio, uide FOERSTER (1903-22). 
Estes exercícios preparavam os jovens fundamentalmente para as causas judiciais e deliberativas. O género epidíctico, por seu turno, é exercitado sobretudo no encómio e no vitupério. Somente após estes exercícios preparatórios é que os jovens se iniciavam nas melétai (declamationes), que compreendiam duas variantes: as hypotéseis dikanikai (controuersiae) e as hypotéseis symbouleutikai (suasoriae). Nestes dois tipos de declamações, os jovens expunham casos completamente fictícios. Nas declamações judiciais inventavam, por exemplo, casos de raptos, violações, histórias de piratas e de filhos deserdados. Nas declamações deliberativas, abordavam temas da mitologia e da historiografia.

De entre o conjunto dos exercícios preliminares, a etopeia constitui um exercício totalmente consagrado às declamações. Os jovens tinham de imaginar os discursos que diriam, por exemplo, Aquiles, Heitor, Sólon, Demóstenes ou Péricles numa determinada situação. É por esta razão que Quintiliano atribui uma grande utilidade ao exercício da etopeia. ${ }^{22}$

Antes de nos determos no estudo da operacionalidade da etopeia no romance bizantino do século XII, observemos, primeiramente, a explicação que os retores dos Progymnasmata nos dão sobre este recurso retórico de longa tradição na literatura grega.

Os exemplos mais antigos de etopeia remontam à épica homérica. E este expediente retórico aparece muito frequentemente em géneros literários muito diversificados. No entanto, é no seio da oratória forense que se tornaram bem delineadas as suas potencialidades. $\mathrm{Na}$ oratória antiga, ethopoeia define-se como um expediente elocutório que tem como principal objectivo tornar o discurso de um litigante o mais apropriado possível à sua pessoa e às circunstâncias com que ele se vê confrontado em tribunal. ${ }^{23}$ Num discurso forense, atendia-se, assim, ao estilo de linguagem e demais informantes que retratavam da forma pretendida o carácter da pessoa em litígio. Esta é a definição originária do conceito de ethopoeia.

Nos Progymnasmata, Hermógenes e Aftónio definem ethopoeia como o recurso retórico responsável pela expressão do carácter de uma determinada figura no momento em que ela profere um discurso. A definição que Hermógenes apresenta é a seguinte: «Uma etopeia ${ }^{24}$ é a imitação do carácter de uma certa pessoa supostamente a falar; por

\footnotetext{
${ }^{22}$ Cf. Quint., Inst. 3.8.50.

${ }^{23}$ Vide DESBORDES (1996) 134-135.

${ }^{24}$ Êthopoiia: de êthos (carácter) e poiéô (criar).
} 
exemplo: "que palavras diria Andrómaca diante do cadáver de Heitor?"25 $[\ldots]$

Há etopeias tanto de figuras conhecidas como de figuras desconhecidas. De figuras desconhecidas, por exemplo: "que palavras diria aos seus familiares um homem que estivesse para se ausentar da sua pátria?" De figuras conhecidas, por exemplo: "que palavras diria Aquiles a Deidamia, quando estava de partida para a guerra?" De entre as etopeias, umas são simples, quando alguém fala consigo próprio; outras são duplas, quando se imagina alguém a falar com outra pessoa. Num discurso consigo próprio, por exemplo: "o que diria um general ao regressar vitorioso?"; num discurso com outra pessoa, por exemplo: "o que diria um general ao seu exército depois da vitória?"

Em todo o exercício, haverá que atender ao que é característico e apropriado às pessoas que se imagina estarem a falar, bem como às ocasiões, pois um discurso de um jovem é diferente do de um ancião, e o de alguém que se encontra alegre também é diferente do de alguém que se encontra em aflição.

Umas etopeias são éticas, outras são emotivas e outras são mistas. São éticas aquelas em que predomina do princípio ao fim a caracterização da pessoa; por exemplo: "o que diria um agricultor ao ver pela primeira vez um navio?" São emotivas aquelas em que se desperta a emoção desde o início ao fim; por exemplo: "que palavras diria Andrómaca diante do cadáver de Heitor?" São mistas aquelas que combinam caracterização e emoção; por exemplo: "o que diria Aquiles diante do cadáver de Pátroclo?", pois a emoção justifica-se pela morte de Pátroclo e o desenvolvimento do carácter observa-se nos planos que Aquiles faz para regressar à guerra. ${ }^{26}$

A elaboração desenvolver-se-á com recurso às três modalidades temporais. Começa pelo presente, dizendo que é penoso; regressa depois ao passado, referindo a partilha da felicidade; passa então para o futuro, dizendo que o que está para vir será muito mais penoso. As formas discursivas e o estilo deverão ser apropriados à caracterização das figuras. ${ }^{27}$

Aftónio apresenta uma definição de etopeia semelhante à de Hermógenes. ${ }^{28} \mathrm{E}$, para completar a sua explicação deste expediente retórico, apresenta, em jeito de exercício resolvido, um exemplo de

${ }^{25}$ Cf. Il. 6.406-439.

${ }^{26}$ Cf. Il. $18.324-342$.

${ }^{27}$ Hermógenes, 20-22 (cf. KenNEDY (2003) 84-85).

${ }^{28}$ Aftónio, 44-46 (cf. KENNEDY (2003) 115-117). 
declamação - "que palavras pronunciaria Níobe quando os seus filhos jaziam mortos?". ${ }^{29}$

Téon, por seu turno, prefere atribuir a este expediente elocutório a denominação de prosopopeia (prosopopoeia), termo que Hermógenes e Aftónio propõem quando se trata de uma personificação (o discurso da pátria, por exemplo), tendo sido este o sentido que a posteridade veio a consagrar para esta palavra. Hermógenes e Aftónio propõem ainda o termo idolopeia (idolopoeia) para a exposição de um discurso proferido por uma pessoa já falecida.

Para estes três retores, fica, no entanto, claro que este recurso retórico toma a forma de um discurso imaginário proferido por uma determinada figura. O exemplo de ethopoeia que Aftónio fornece - o discurso de Níobe ao ter perdido todos os seus filhos - é extraído do universo mitológico. Em Bizâncio, Nicéforo Basílaces fornece-nos vinte e sete exemplos de ethopoeia, todos eles iniciados com a seguinte fórmula: o que figura tal diria em $x$ situação. ${ }^{30}$ Os temas que trata reportam-se não só à tradição mitológica, mas também à tradição cristã. Os exemplos de etopeia apresentados por Nicéforo Basílaces demonstram claramente que este recurso retórico era muito apreciado pelos bizantinos. Neste contexto, a criação romanesca bizantina tornase, por conseguinte, um terreno fértil para a elaboração deste tipo de discursos imaginários, que, por sua vez, passam a ser atribuídos a figuras ficcionais.

As normas postuladas pelos retores para o estabelecimento de uma ethopoeia no âmbito geral do exercício oratório tornaram-se modelos indispensáveis para o exercício da composição literária. Dos três géneros discursivos que a tradição consagrou (o deliberativo, o judicial e o epidíctico), ${ }^{31}$ é o género epidíctico que recebe um mais profícuo acolhimento na literatura bizantina. Nesta predilecção, os bizantinos partilham os ideais defendidos pela Segunda Sofistica. Neste movimento cultural, os discursos do género epidíctico, pronunciados para louvar ou censurar uma individualidade, uma actividade ou uma coisa, eram, de facto, os que estavam em voga. O género deliberativo e o género judicial tinham perdido a amplitude que o sistema democrático da cidade-estado lhes havia concedido.

Dada a gratuidade que o caracterizava, o género epidíctico, que não implicava um processo de decisão, mostrou-se terreno fértil para a

\footnotetext{
${ }^{29}$ Libânio também nos fornece dois exemplos de etopeia que se reportam a esta mesma história mitológica (cf. FOERSTER (1963) 391-396).

${ }^{30}$ Cf. Pignani (1983) 139-232 (Prog. VII).

${ }^{31}$ Cf. JúNIOR (2004) 30-32.
} 
prática literária. $\mathrm{O}$ género deliberativo obrigava ao assentimento ou refutação dos argumentos expostos. Os membros da assembleia tinham por sua obrigação apresentar uma decisão: ou eram a favor ou contra. Nos tribunais, exigia-se aos juízes e jurados que condenassem ou absolvessem. Por seu lado, o discurso epidíctico exigia da parte do público o louvor ou a censura e, acima de tudo, uma apreciação de natureza estética. $\mathrm{O}$ objectivo deste género do discurso não se limitava à persuasão. Procurava-se, igualmente, agradar, porque se apresentava como um discurso-espectáculo. ${ }^{32} \mathrm{E}$, contrariamente ao que sucedia nos restantes géneros discursivos, a arte da palavra tornava-se bem visível, em vez de surgir camuflada. Tratava-se, assim, de um género aberto a inovações. E é, nesta conformidade, que o género epidíctico acolhe o discurso ficcional.

No romance bizantino do século XII, à semelhança do que sucede no seu congénere antigo, torna-se perfeitamente clara a assimilação que o género romanesco faz da prática retórica. Por exemplo, a relevância que é dada à ethopoeia explica, de algum modo, a necessidade que os romancistas tiveram de se socorrer deste expediente retórico. No processo de concatenação e alternância de discursos do narrador e discursos das personagens, há no romance bizantino do século XII uma predilecção pelo discurso directo. No romance de Teodoro Pródromo, $62,6 \%$ compreende discurso directo. No romance de Nicetas Eugeniano, a percentagem de discurso directo atinge os $68,3 \%$. E, em particular, o romance de Eumátio Macrembolites, contado na primeira pessoa, toma a configuração lato sensu de uma longa ethopoeia. Assim, uma parte significativa desta produção literária é constituída pelo discurso directo sob a forma de monólogo ou diálogo.

A inserção da ethopoeia no contexto da produção romanesca assegura uma duração literária e atribui ao enunciado uma carga narrativa. As inúmeras etopeias que surgem disseminadas ao longo da narrativa conferem uma grande elasticidade ao fio condutor da intriga. Surgem como recursos de amplificação, que aprofundam o delineamento do carácter das personagens, ao mesmo tempo que vão marcando o ritmo narrativo, sob a forma de pequenos clímaxes.

A disposição da ethopoeia detém, assim, uma função geotextual, uma vez que obedece a critérios narrativos bem delineados, que são conjugados de acordo com o horizonte de expectativa do público leitor ou auditor. O imediatismo proporcionado pela citação confere à sequência narrativa uma feição dramática, ao mesmo tempo que se

\footnotetext{
${ }^{32}$ Cf. Desbordes (1996) 131-132.
} 
insurge como veículo actualizador dos principais acontecimentos ocorridos. Quem lê ou ouve a história romanesca pode, através da etopeia, ouvir as personagens. O efeito de real concretiza-se eficazmente. E, muitas das vezes, as falas das personagens são recapitulatórias, em solilóquios ou em etopeias duplas. Os principais acontecimentos são retomados, de modo a criar uma tensão dramática que tem como último objectivo adensar o páthos amoroso. Trata-se de etopeias emotivas - segundo a terminologia de Hermógenes.

Em última instância, a etopeia contribui, de modo bastante significativo, para o processo geral de caracterização personagística, uma vez que o seu principal propósito é o desenvolvimento do carácter (êthos) das personagens postas em cena. A personagem literária define-se essencialmente como uma categoria narrativa gravitacional, à volta da qual se desenvolve a acção; e assume uma função centralizadora na organização da economia narrativa. Na qualidade de elemento estruturante da concretização do processo narrativo, a personagem também se define em função das conexões que se estabelecem no interior da narrativa. Na verdade, os traços constitutivos da personagem de romance são delineados por marcas intrínsecas e extrínsecas que pertencem a vários níveis narrativos, descritivos ou discursivos. ${ }^{33} \mathrm{E}$ a identidade de uma personagem resulta de uma cooperação produtiva entre o texto e o leitor. ${ }^{34}$

No romance bizantino do século XII, o esquema de caracterização personagística segue as regras que, de um modo geral, prevalecem neste processo narrativo. ${ }^{35}$ Com efeito, a caracterização de personagens

${ }^{33}$ Cf. ReIS \&LOPES (1987) 306-315. Cf., ainda, HAMON (1977).

${ }^{34}$ Cf. Jouve (1992) 27.

${ }^{35}$ Os atributos que identificam as personagens evidenciam-se, ora através de uma caracterização directa, ora através de uma caracterização indirecta. No primeiro caso, trata-se de descrições fisicas e psicológicas veiculadas pelo narrador ou por qualquer personagem inserida no esquema actancial, constituindo estas descrições fragmentos discursivos estáticos, elaborados com essa mesma finalidade. No segundo caso - o da caracterização indirecta -, os traços que identificam a personagem surgem disseminados ao longo da narrativa. A personagem vai sendo construída de forma gradual, à medida que a narrativa progride. $\mathrm{O}$ conjunto dos atributos da personagem é facultado, por exemplo, pelos discursos que ela própria profere, pelos seus actos e reacções para com outras personagens; em suma, pelo total das informações que vão sendo disponibilizadas ao leitor (cf. REIS \& LOPES (1987) 306-315). Neste processo manifestamente dinâmico, as personagens vão sendo desenhadas episódio a episódio na imaginação do leitor, ou do ouvinte, se atendermos ao público a quem os romances bizantinos foram destinados, uma vez que se julga que estes romances, ou pelo menos alguns trechos, foram declamados (cf. ARRIGNON \& DUNEAU (1992) 285). 
projecta-se sobre domínios específicos da construção de uma narrativa. Através deste processo narrativo, assiste-se à transmissão de uma mensagem de cepticismo relativamente a um conjunto de valores.

Nos fragmentos que possuímos do romance de Constantino Manasses,${ }^{36}$ de pendor profundamente aforístico, algumas passagens são elucidativas desse cepticismo. Em relação ao daímōn, refere-se o seguinte: "A divindade é maligna e invejosa e esforça-se por destruir sempre os ricos, os sábios e os belos" (Man. 9.171); afirma-se também que os sonhos iludem (Man., 8.152). E, no que diz respeito ao próprio ser humano, são tecidos os seguintes comentários: "a estirpe infelicíssima dos homens é lançada à nascença num mar de infortúnios" (Man., 4.69); "O homem não é uma planta celeste nem divina, nem uma árvore cultivada pela mão do deus, mas sim um passatempo da divindade e um joguete do Destino! (...) como é incerta toda a forma de vida e toda a existência do homem!" (Man., 9.159). Esta mesma ordem de ideias surge repetida noutros passos, nos quais se põe em evidência fundamentalmente a ideia de que o ser humano está entregue ao livre arbítrio e de que tudo é instável na sua existência. ${ }^{37}$

À semelhança dos protagonistas do romance grego antigo, os heróis dos romances bizantinos do século XII assemelham-se aos deuses e, inclusive, chegam a ser confundidos com eles mesmos. Rodante é comparada a Ártemis (Pród., 1.41); Dósicles encarna a figura de um verdadeiro deus (Pród., 7.238).

A aparência divina que os heróis ostentam constitui um factor determinante para a experiência do amor que lhes é dada a conhecer. De um modo geral, apaixonam-se ao primeiro olhar, de forma instantânea e hipnótica, por ocasião de uma festa religiosa. Através do olhar, um encontra no outro o reflexo da juventude e beleza de si próprio. No caminho cruzado de olhares, cada um serve ao outro de espelho. Uma vez desencadeado esse reflexo, eles crêem que jamais poderão viver separados. E, por isso, fazem juramentos de fidelidade mútua. Na realidade, existe entre os dois enamorados uma sintonia perfeita - a "sexual symmetry", como designou David KONSTAN relativamente ao tema do amor dos heróis do romance antigo. ${ }^{38}$ Ambos são jovens, são belos e bem formados - almas gémeas. A partir do momento em que se dá início ao diálogo erótico, os dois jovens tomam consciência da

${ }^{36} \mathrm{Em}$ todas as referências aos romances bizantinos do século XII, seguimos a edição de CONCA (1994).

${ }^{37}$ Cf. Man., $1.8 ; 1.10 ; 1.21 \mathrm{a} ; 3.49 ; 3.54 ; 3.59 ; 4.76 ; 4.83 ; 5.94 ; 6.108 ; 7.137$.

${ }^{38}$ Cf. Konstan (1994) 14-59 e Fusillo (1991) 201-212. 
incompletude que caracteriza o próprio ser humano, pois Eros não sobrevive sem Ânteros, o amor recíproco. Da experiência do amor, os heróis retiram um conhecimento: a impossibilidade de o ser humano se poder limitar a si próprio. A heroína do romance de Nicetas Eugeniano, Drosila, está consciente disto mesmo, ao afirmar que, se Cáricles não quiser amá-la do fundo do seu coração, ela terá somente metade da vida que deseja para si (Eug., 5.35-36).

Aqueles que manifestam relutância em aceitar facilmente esse conhecimento que é transmitido através da experiência do amor são atormentados por Eros, de tal ordem que acabam por tornar-se seus escravos submissos. Hismínias, o herói do romance de Eusmátio Macrembolites, mostra-se insolente para com Eros, ao não aceitar facilmente ser ferido pelas flechas do deus. Somente depois de ser alvo dos ataques violentos e sistemáticos desferidos por Eros, que ocorrem através de sonhos, é que Hismínias se rende completamente aos encantos de Hismine. Também Calidemo, uma personagem do romance de Nicetas Eugeniano, desprezava o amor antes de conhecer Drosila: ele acreditava "falaciosamente" - segundo acentua o narrador - que poderia não ser subjugado pela beleza; não gostava de discursos amorosos e não conhecia o desejo; desdenhava também dos sofrimentos daqueles que amavam e tinha aversão pelas núpcias (Eug., 6.332343). Paradoxalmente, depois de ser apanhado nas malhas do deus, Calidemo revela-se um sábio das teorias da ars amatoria, como se pode observar no longo discurso que ele profere sobre o tema do amor (Eug., 6.332-558).

Neste discurso recheado de referências mitológicas e literárias, Calidemo tenta persuadir Drosila a ceder à sua paixão, dando como exemplum o amor de Ársace por Teágenes e o de Aquémenes por Caricleia (Eug., 6.382-390). E estas não são as únicas referências intertextuais que podem ser encontradas no romance de Nicetas Eugeniano. Calidemo refere-se ainda aos protagonistas do romance de Longo (Eug., 6.440-451), dizendo que o olhar de Cloe era fogo para Dáfnis; as suas palavras, um arco; e os seus abraços, flechas (Eug., 6.450-451). Cloe surge, assim, como a personificação do próprio deus do amor.

Através de uma referência nítida a Hesíodo, Calidemo afirma ainda que a idade do bronze é aquela em que o amado não quer corresponder ao amor (Eug., 6.452-455). Ao não ceder aos intentos do filho de Xenócrates, para manter o juramento de fidelidade para com Cáricles, Drosila é para Calidemo um "émpnoos lithos" - uma "pedra que respira" (Eug., 6.618). Este é um dos exemplos em que a beleza assombrosa dos protagonistas se revela um perigo iminente para a pre- 
servação da sua castidade. Reconhecida por todos quantos travam conhecimento com os heróis, a ostentação de uma tal beleza se, por um lado, confere um grau de distinção e nobreza, por outro lado, é motivo de inúmeros perigos para os protagonistas, pois faz despoletar paixões irreprimiveis naqueles que são tocados pelos seus encantos.

Como se pode observar nos exemplos acima apresentados, Eros revela-se inflexível para com aqueles que menosprezam os seus poderes, porque esta atitude corresponde a uma afronta declarada aos deuses. Na verdade, o ser que se julga na posse da sua integralidade, arrogando-se da sua autoconfiança e estima, está naturalmente a agir contra as leis estabelecidas pelos deuses e, por conseguinte, a provocar o ciúme divino. Aos olhos dos deuses, o mortal que se sente no poder da plenitude, da eterna felicidade, está possuído de hybris - "insolência -, visto que tem a ousadia de usufruir de um bem que só aos deuses pertence. E não é do agrado dos deuses aceitar tal atitude, porque, na óptica dos seres divinos, o amor que deve estar ao alcance dos mortais é aquele que corresponde à experiência da própria incompletude, isto é, ao conhecimento da impossibilidade de o ser se satisfazer com aquilo que é. Consciente desta verdade, Cáricles afirma que é terrível amar, mas mais ainda não amar (Eug., 5.146). Sobressai, assim, a ideia de que amar é ser-se irremediavelmente mortal; e não amar é ser-se audaciosamente divino, como propõe Jean-Pierre VERNANT, ao abordar a relação do homem grego com os deuses ${ }^{39}$

Por conseguinte, aquele que recusa a experiência do amor colocase de modo pretensioso na esfera do divino, não reconhecendo que Eros é filho da Penía (Pobreza), segundo a tradição platónica. No Simpósio (203b-212c), Platão coloca na voz de Diotima a opinião de que o amor nasceu da união de Póros (Expediente) com a Penía (Pobreza). Assim, dos seus progenitores, o Amor herdou as seguintes qualidades: saber sempre encontrar um meio para atingir os seus fins e buscar incessantemente o objecto do seu desejo.

O percurso amoroso dos protagonistas do romance bizantino do século XII parece, efectivamente, obedecer a este princípio. Os heróis

${ }^{39}$ Cf. VERNANT (1989) II-III: «Dans une religion polythéiste les dieux, comme les hommes sont des individus, mais immortels; ils ignorent toutes les imperfections, les lacunes, les insuffisances qui constituent, chez les mortels, la nécessaire contrepartie, le prix à payer pour une forme individualisée d'existence. Si beau que soit un être humain son pauvre corps ne vaut jamais que comme un reflet obscurci, déficient, incertain du corps des dieux dans l'éclat inaltérable de leur splendeur. Pour être lui-même, dans la singularité de sa vie, il lui faut aussi, au miroir du destin, se mesurer a ce modèle inaccessible, cet au-delà auquel il ne saurait prétendre.» 
socorrem-se de todos os meios ao seu alcance para que possam fruir plenamente do amor que os uniu; e, entre ambos, desencadeia-se uma atracção irresistível que não mais os abandonará. Como não consideram possível viver felizes na sua pátria, receando que a sua união seja uma afronta para os seus pais, que para eles têm marcados outros destinos, resolvem fugir para terras distantes, onde julgam poder viver em paz a sua felicidade.

É por este motivo que o início do amor corresponde a um verdadeiro prognóstico de itinerância. A fuga que os jovens empreendem assume-se como um acto de rebeldia precipitado que os expõe a toda uma série de infortúnios: tempestades, raptos, escravatura, violência de piratas e ladrões. Durante o período em que estão fora da sua pátria, os heróis passam necessariamente por um processo de formação. As múltiplas e variadas contrariedades com que se confrontam não lhes são indiferentes. Nos monólogos em que lamentam a sua sorte e passam em revista os infortúnios que os têm atingido, eles mostram reflectir no caos a que o Destino os condenou.

Não se conformando com o acto irreflectido da sua fuga da pátria, e temendo pelo perigo a que expôs Rodante, Dósicles afirma: "Eu não conhecia os reveses do destino? Eu não sabia que os viajantes se expõem a emboscadas e a ataques de piratas, e os navegantes se encontram com a tempestade e com a frota de piratas? Por que é que então, conhecendo eu as vicissitudes arrevesadas da vida, te levei como um inimigo para uma terra estrangeira, roubando-te aos braços dos teus pais?" (Pród., 6.355-361). Dósicles condena-se a si próprio, por ter tido a ilusão de que, em terras estrangeiras, iria encontrar a sua felicidade com Rodante. Condena-se, por não ter ponderado estoicamente nos riscos em que a fuga os poderia colocar. Condena-se, por ter agido como um cego perante uma decisão que, à partida, denunciava os seus próprios riscos. Acusa a Inveja (Phthónos: Pród. 6.372) de não ter permitido que as suas esperanças se tornassem realidade. E revoltase contra Hermes, o deus que abençoara a sua união com Rodante, afirmando que de nada servem as palavras dos deuses. Por fim, Dósicles remata: "E quem não se deixaria levar por discursos mentirosos, para ser semelhante aos imortais?" (Pród., 6.402-403). Através destas palavras, Dósicles deixa perceber que a vida dos mortais é um logro.

Por conseguinte, da mesma forma que a ekphrasis, a ethopoeia constitui um expediente retórico de grande relevância na arte de composição romanesca. No romance bizantino do século XII, a ethopoeia é responsável pelo ritmo imprimido ao desenvolvimento dos principais acontecimentos. Ocorre em momentos cruciais da história romanesca: 
nos momentos em que a voz do narrador tem de ser substituída pela voz das personagens, pois o discurso a viva voz presentifica a acção e confere-lhe uma mais profunda carga narrativa. Os discursos das personagens, na maioria dos casos recapitulatórios, apelam a um mais activo comprometimento por parte do público leitor ou auditor no seguimento da narrativa. Num solilóquio, por exemplo, a personagem fala e o público torna-se seu confidente. E, entre os temas mais abordados na ethopoeia, adquirem maior relevância as relações entre o ser humano e o destino, bem como as vicissitudes desencadeadas pelo páthos amoroso.

\section{Bibliografia}

Panagiotis A. AGAPITOS, "Poets and Painters: Theodoros Prodromos' Dedicatory Verses of his Novel to an Anonymous Caesar", JÖB 50 (2000) 173-185.

Graham ANDERSON, "The pepaideumenos in Action: Sophists and their Outlook in the Early Roman Empire”, ANRW II.33.1 (1989) 79-208.

Michael ANGOLD (ed.), The Byzantine Aristocracy IX to XIII Centuries (Oxford, OUP, 1984).

Michael ANGold, The Byzantine Empire, 1025-1204. A Political History (London, Longman, $1997^{2}$ ).

Jean-Pierre ARRIGNON \& Jean-François DUNEAU, "Le Roman Byzantin: Permanence et Changements", in Marie-Françoise BASLEZ, Philippe HofFMANN \& Monique Trede (eds.), Le Monde du Roman Grec (Paris, Presses de l'École Normale Supérieure, 1992) 283-290.

Roderick BEATON, The Medieval Greek Romance (London/ New York, Routledge, $\left.1996^{2} a\right)$.

Roderick BEATON, "The Byzantine Revival of the Ancient Novel", in G. Schmeling (ed.), The Novel in the Ancient World (Leiden/ New York/ Köln, E. J. Brill, 1996b) 71-733.

Ewen L. BowIE, "Greek Sophists and Greek Poetry in the Second Sophistic", $A N R W$ II.33.1 (1989) 209-258.

Joan B. Burton (introd., trad. e notas), Nicetas Eugenianos. A Byzantine Novel: Drosilla and Charikles (Wauconda - IL, Bolchazy-Carducci Publishers, Inc., 2004).

James BuTTS (ed.), The "Progymnasmata" of Theon: A New Text with Translation and Commentary (Dissertation, Claremont Graduate School, 1986).

Fabrizio Conca (ed.), Nicetas Eugenianus. De Drosillae et Chariclis Amoribus (Amsterdam, J. C. Gieben, 1990).

Fabrizio ConCA (ed. e trad.), Il Romanzo Bizantino del XII Secolo: Teodoro Prodromo - Niceta Eugeniano - Eustazio Macrembolita - Costantino Manasse (Torino, UTET, 1994). 
Costas N. CONSTANTINIDES, "Teachers and students of rhetoric in the late Byzantine period", in Elizabeth JEFFREYS (ed.), Rhetoric in Byzantium (Aldershot/ Burlington, Ashgate, 2003) 39-53.

Jacques DERrIDA, “The Law of Genre”, Glyph. Textual Studies 7 (1980) 177-185.

Françoise DESBORDES, La Rhétorique Antique. L'Art de Persuader (Paris, Hachette, 1996).

Joseph Felten (ed.), Nicolai Progymnasmata (Leipzig, Teubner, 1913).

Richard FoERSTER (ed.), Libanii Opera, 12 vols. (1903-22 [reimpr. Hildesheim, Olms, 1963]).

Massimo Fusillo, Naissance du roman (Paris, Seuil, 1991).

Marília Futre PInHeIro, Literatura Grega II. Programa, Conteúdos, Métodos e Bibliografia (Lisboa, Universidade de Lisboa, 2000).

Philippe HAMON, "Pour un statut sémiologique du personnage", in R. BARTHES et alii., Poétique du récit (Paris, Éditions du Seuil, 1977).

Ronald F. Hock, J. B. Chance \& J. Perkins (eds.), Ancient Fiction and Early Christian Narrative (Atlanta, Scholars Press - Society of Biblical Literature, 1998).

Herbert Hunger, Die hochspraliche profane Literatur der Byzantiner, 2 vols. (München, Beck, 1978).

Herbert HUNGER, "Die Makremboliten auf byzantinischen Bleisiegeln und in sonstigen Belegen”, Studies in Byzantine Sigillography 5 (1998) 1-28.

Elizabeth JEFFrEYs, "The Comnenian Background to the Romans d'Antiquite", Byzantion 50 (1980) 455-486.

Elizabeth JefFreYs (ed.), Rhetoric in Byzantium (Aldershot/Burlington, Ashgate, 2003).

Vincent JOUVE, "Le personnage comme produit de l'interaction texte/lecteur", L'effet-personnage dans le roman (Paris, Presses Universitaires de France, 1992).

Manuel Alexandre JúNIOR, Hermenêutica Retórica. Da Retórica Antiga à Nova Hermenêutica do Texto Literário (Lisboa, Livraria Espanhola, 2004).

Alexander P. KAZHDAN, "Theodore Prodromus: A Reappraisal", in Alexander P. KAZHDAN \& Simon Franklin, Studies on Byzantine Literature of the Eleventh and Twelfth Centuries (Cambridge, CUP, 1984).

George A. Kennedy (introd., trad. e notas), Progymnasmata. Greek Textbooks of Prose Composition and Rhetoric (Leiden/Boston, Brill, 2003).

David Konstan, Sexual Symmetry. Love in the Ancient Novel and Related Genres (Princeton/New Jersey, Princeton University Press, 1994).

O. LAMPSIDIS (ed.), Constantini Manassis Breviarium Chronicum - CFHB 36, 1-2 (Athens, 1996).

Paul Magdalino, The Empire of Manuel I Komnenos, 1143-1180 (Cambridge, CUP, 1993).

Miroslav MARCovich (ed.), Theodori Prodromi, de Rhodanthes et Dosiclis Amoribus Libri IX (Stutgardiae et Lipsiae, Teubner, 1992).

Miroslav MARCovich (ed.), Eustathius Macrembolites. De Hysmines et Hysminiae Amoribus Libri XI (Monachii et Lipsiae, Teubner, 2001). 
Otto MAZAL (ed.), Der Roman des Konstantinos Manasses. Überlieferung, Rekonstruktion, Textausgabe der Fragmente (Wien, Hermann Böhlaus Nachf,, 1967).

Florence MEUnIER (introd. e trad.), Eumathios. Les Amours Homonymes. Roman (Paris, 1991).

José Antonio Moreno Jurado (trad.), Teodoro Pródromos. Rodante y Dosicles (Madrid, Ediciones Clásicas, 1996).

Ingela NiLsson, Erotic Pathos, Rhetorical Pleasure. Narrative Technique and Mimesis in Eumathios Makrembolites' Hysmine \& Hysminias (Uppsala, Acta Universitatis Upsaliensis 7, 2001).

Michel Patillon \& Giancarlo Bolognesi (eds.), Aelius Theon. Progymnasmata (Paris, Les Belles Lettres, 1997 [2. ${ }^{a}$ tir. 2002]).

Richard Pervo, "The Ancient Novel Becomes Christian", in G. Schmeling (ed.), The Novel in the Ancient World (Leiden/ New York/ Köln, E. J. Brill, 1996) 685-709.

Adriana Pignani (ed. e trad.), Niceforo Basilace. Progimnasmi e Monodie (Napoli, Bibliopolis, 1983).

Karl Plepelits (trad.), Eustathios Makrembolites. Hysmine und Hysminias. Eingeleitet, übersetzt und erläutert (Stuttgart, A. Hiersemann, 1989).

Karl Plepelits (introd. e trad.), Theodoros Prodromos. Rhodanthe und Dosikles (Stuttgart, A. Hiersemann, 1996).

Karl PlePelits (introd., trad. e com.), Niketas Eugenianos. Drosilla und Charikles (Stuttgart, A. Hiersemann, 2003).

Hugo RaBE (ed.), Hermogenis Opera (Leipzig, Teubner, 1926).

Hugo Rabe (ed.), Aphthonii Progymnasmata (Leipzig, Teubner, 1913 [reimpr. 1969]).

Maria Dolores Reche Martinez (introd., trad. e notas), Teón. Hermógenes. Aftonio. Ejercicios de Retórica (Madrid, Editorial Gredos, 1991).

Carlos ReIS, O Conhecimento da Literatura. Introdução aos Estudos Literários (Coimbra, Livraria Almedina, 1995).

Carlos ReIs \& Ana Cristina M. LoPES, Dicionário de Narratologia (Coimbra, Livraria Almedina, 1987).

Gareth Schmeling, Xenophon of Ephesus (Boston, Twayne Publishers, 1980).

Leonardus SPENGel (ed.), Rhetores Graeci, 3 vols. (Leipzig, Teubner, 1854-56 [reed. por Caspar HammER: Leipzig, Teubner, 1894]).

Jean-Pierre Vernant, L'Individu, La Mort, l'Amour: Soi-même et l'autre en Grèce Ancienne (Paris, Éditions Gallimard, 1989).

Christian WaLZ (ed.), Rhetores Graeci, 9 vols. (London, 1832-36 [Osnabrück, Zeller, 1968]).

N. G. WILson, Scholars of Byzantium (London, Duckworth, 1996 [1983]). 